\title{
Screening and Characterization of Hydrocarbonoclastic Bacteria Isolated from Oil-contaminated Soils from Auto Garages
}

\author{
Agnes Njoki Mwaura ${ }^{1,}$, Betty Nyambura Mbatia ${ }^{2}$, Edward Kirwa Muge ${ }^{1}$, Patrick Wafula Okanya ${ }^{3}$ \\ ${ }^{1}$ Department of Biochemistry, University of Nairobi, Nairobi, Kenya \\ ${ }^{2}$ School of Pharmacy and Health Sciences, United States International University - Africa, Nairobi, Kenya \\ ${ }^{3}$ Department of Biochemistry and Biotechnology, Technical University of Kenya, Nairobi, Kenya \\ Email address: \\ njokimwaura8@gmail.com (A. N. Mwaura) \\ ${ }^{*}$ Corresponding author
}

\section{To cite this article:}

Agnes Njoki Mwaura, Betty Nyambura Mbatia, Edward Kirwa Muge, Patrick Wafula Okanya. Screening and Characterization of Hydrocarbonoclastic Bacteria Isolated from Oil-contaminated Soils from Auto Garages. International Journal of Microbiology and Biotechnology. Vol. 3, No. 1, 2018, pp. 11-24. doi: 10.11648/j.ijmb.20180301.13

Received: January 10, 2018; Accepted: February 1, 2018; Published: March 23, 2018

\begin{abstract}
Release of petroleum oil and its products into the environment is a worldwide concern. The present study focused on isolation, molecular identification, morphological and biochemical characterization of bacteria possessing hydrocarbondegrading properties. The study also aimed at optimizing appropriate culture conditions for the isolates as well as screening for alkane hydroxylase enzyme. Out of twenty one microbes isolated, nine were selected based on their ability to utilize different hydrocarbons. The isolates were observed to mineralize heating oil, hexane, octane, toluene and diesel oil. PCR amplification of $16 \mathrm{~S}$ rDNA gene revealed that the isolates belong to six different genera; Pseudomonas, Acinetobacter, Klebsiella, Enterobacter, Salmonella and Ochrobactrum. Based on their ability to degrade diesel oil, three isolates were selected and their growth conditions optimized. Optimum degradation was recorded at less than $1 \%$ substrate concentration, $\mathrm{pH} 7$ and temperature range of between $30^{\circ} \mathrm{C}$ and $37^{\circ} \mathrm{C}$ and using yeast extract as nitrogen source. GC-MS analyses confirmed their diesel oil degrading properties. Alkane hydroxylase gene from one of the isolates (isolate 1C) was successfully amplified indicating its catabolic capabilities in degrading alkanes. Overall, the characterized isolates may constitute potential candidates for biotechnological application in environmental cleanup of petroleum contaminants.
\end{abstract}

Keywords: Oil-Contaminated Soils, Bacteria, Biodegradation, Petroleum Hydrocarbons

\section{Introduction}

Petroleum-based products are a principle source of energy for industries and daily life, making them a vital commodity central to the global economy [1]. They originate from crude oil whose main constituents are hydrocarbon compounds derived from ancient algae and plant remains found in reservoirs under the earth's surface [2]. Petroleum products are divided into four classes: saturates, aromatics, resins and asphaltenes [3]. Accidental release of petroleum products occur regularly during exploration, production, refining, transportation, utilization and storage [4]. It is estimated that globally, approximately 1.7-8.8 million metric tons of petroleum hydrocarbons are released into marine ecosystems annually [5]. Water and soil pollution is a worldwide environmental problem that is of particular concern since it leads to uptake and accumulation of toxic substances including petroleum products in food chains consequently harming the flora and fauna [6]. Current conventional disposal methods of petroleum products include physicochemical techniques such as photo-oxidation, burying, dispersion, washing, incineration, thermal conversion and other pyrolysis techniques [5,7]. However, many of these methods are expensive and can result in incomplete decomposition of oil products. In addition, physicochemical methods such as volatization, photooxidation and chemical oxidation are rarely successful in rapid removal of hydrocarbon contaminants especially the aromatics [8]. 
Bioremediation is emerging as one of the most promising technologies for environmental removal of petroleum contaminants [1]. It is a process through which microorganisms metabolize contaminants through oxidative/reductive processes. Bioremediation can be carried out either through addition of oil degrading microbes into the soil in a process referred to as bio-augmentation or through provision of appropriate conditions and/or amendments (e.g. supplying oxygen, moisture and nutrients) for growth of the microorganisms in the soil, a process known as biostimulation [4]. Studies have shown that petroleum-based products can primarily be eliminated from the environment by microbes such as bacteria, yeast, fungi and microalgae [1]. Bacteria however play a major role in biodegradation of these hydrocarbon compounds. Some important microbial species with this potential are of the genera Bacillus, Arthrobacter, Halononas, Pseudomonas, Klebsiella, Proteus among others [9]. These microbes completely degrade (mineralize) organic compounds into non-toxic end products that include carbon dioxide and water or organic acids and methane [6]. Bioremediation is therefore an effective technique that takes advantage of the versatility of microbes to completely degrade petroleum compounds into innocuous end products. Apart from being environmentally friendly, the method is also cost effective for treatment of oil pollution compared to physicochemical methods [10].

Although numerous studies have been conducted on microbial species capable of cleaning up petroleum contaminants around the world, Kenya has not adopted this emerging technology and no data exists on its potential application in environmental conservation. The significance of this work is that this is the first report on isolation and characterization of oil degrading bacteria in the country. With the ongoing oil explorations in East Africa region, accidental oil spills are likely to occur during drilling or transportation. The objective of the current study was therefore to screen, characterize (using morphological, biochemical and molecular methods) and optimize appropriate culture conditions for oil degrading microbes that would be best suited to degrade petroleum-based contaminants. This will provide insight on an effective strategy that can be used to clean up accidentally released petroleum oil and hence provide a possible effective oil spill response management strategy to oil prospecting, refining and transporting companies and the general public.

\section{Materials and Methods}

\subsection{Sample Collection}

Soil samples from the surfaces to a depth of about $15 \mathrm{~cm}$ were collected from six sites denoted as sites 1 to 6 in garages around Ngara area in Nairobi-Kenya. The collected samples were kept in sterile falcon tubes prior to transportation to the laboratory and stored at $-20^{\circ} \mathrm{C}$.

\subsection{Bacteria Isolation}

Isolation of hydrocarbon degrading bacteria was carried out using enrichment technique [11]. Soil sample (1 g) from each site was transferred into $250 \mathrm{ml}$ Erlenmeyer flasks containing $100 \mathrm{ml}$ sterile Bushnell Haas media (BHM) $\left\{\mathrm{g} \mathrm{l}^{-1}\right.$ : $\mathrm{MgSO}_{4}$ (0.2), $\mathrm{CaCl}_{2}$ (0.02), $\mathrm{KH}_{2} \mathrm{PO}_{4}$ (1.0), $\mathrm{K}_{2} \mathrm{HPO}_{4}$ (1.0), $\mathrm{NH}_{4} \mathrm{NO}_{3}$ (1.0), $\mathrm{FeCl}_{3}$ (0.05) final $\left.\mathrm{pH} 7\right\}$ [12] supplemented with $1 \%$ used engine oil as sole carbon source and incubated at $37^{\circ} \mathrm{C}$ for 7 days in a rotary shaker (Gallenkamp, England) operating at 120 revolutions per minute (rpm). An inoculum was then picked from each BHM flask and streaked on to Luria Bertani (LB) agar plates $\left\{\left(\mathrm{g} \mathrm{l}^{-1}\right.\right.$ : Tryptone (10.0), Yeast extract (5.0), $\mathrm{NaCl}$ (10.0), Agar (15.0) final $\mathrm{pH} \mathrm{7.2 \}}$ and incubated overnight at $37^{\circ} \mathrm{C}$. Colonies were picked from each plate, transferred into test tubes containing LB broth and incubated in a rotary shaker at $200 \mathrm{rpm}$ for 24 hours at $30^{\circ} \mathrm{C}$. Serial dilutions of up to $10^{\wedge-7}$ from each test tube was done and an aliquot of $100 \mu 1$ plated on LB agar plates. Discrete colonies (from $10^{\wedge^{-7}}$ and $10^{\wedge^{-6}}$ dilutions plates) were then picked and purified by plating on fresh LB agar plates and later LB broth before storage at $4^{\circ} \mathrm{C}$.

\subsection{Screening for Degradation}

Pure isolates were screened for their ability to metabolize heating oil using the procedure described by [11]. Minimal media supplemented with heating oil as the sole carbon source was used. Bacterial cells previously cultured overnight in LB media were washed twice with $0.85 \% \mathrm{NaCl}$ solution before suspending in the same solution. An aliquot $(100 \mu \mathrm{l})$ of bacterial culture was then transferred to test tubes containing 5 $\mathrm{ml}$ minimal media following autoclaving for 15 minutes at $121^{\circ} \mathrm{C}$. Heating oil $(0.5 \mathrm{ml})$ was then added and incubation carried out at $37^{\circ} \mathrm{C}$ in a shaker at $150 \mathrm{rpm}$. Minimal media composition $\mathrm{g} \mathrm{l}^{-1}$ : $\left(\mathrm{NH}_{4}\right)_{2} \mathrm{SO}_{4}(1.0), \mathrm{MgSO}_{4} .7 \mathrm{H}_{2} \mathrm{O}$ (0.1), $\mathrm{KH}_{2} \mathrm{PO}_{4}(0.5), \mathrm{K}_{2} \mathrm{HPO}_{4}(0.76)$. Composition of $\mathrm{ml} \mathrm{l}^{-1}$ trace elements solution (mg l-1): $\mathrm{ZnSO}_{4}$ (100), $\mathrm{H}_{3} \mathrm{BO}_{3}$ (300), $\mathrm{CaCl}_{2} .2 \mathrm{H}_{2} \mathrm{O}$ (134.2), $\mathrm{FeSO}_{4} .7 \mathrm{H}_{2} \mathrm{O}$ (2000), $\mathrm{CuCl}_{2} .2 \mathrm{H}_{2} \mathrm{O}$ (10), $\mathrm{NaMoO}_{4} \cdot 2 \mathrm{H}_{2} \mathrm{O}(30), \mathrm{NiCl}_{2} \cdot 6 \mathrm{H}_{2} \mathrm{O}(20), \mathrm{MnCl}_{2} \cdot 4 \mathrm{H}_{2} \mathrm{O}$ (30). The $\mathrm{pH}$ was adjusted to 7 using $1 \mathrm{M} \mathrm{NaOH}$. Bacterial isolates were also screened for their ability to degrade toluene, octane and hexane. Pure bacterial cultures were streaked on Bushnell Haas agar plates that were kept in a desiccator containing $10 \%$ toluene and $90 \%$ hexadecane in a $25 \mathrm{ml}$ beaker and incubated at $25^{\circ} \mathrm{C}$ for 14 days. Isolates were also separately exposed to $20 \%$ hexane in $80 \%$ hexadecane and $20 \%$ octane in $80 \%$ hexadecane and treated as described for toluene. Un-inoculated plates were kept as control.

\subsection{Morphological Identification}

Bacterial isolates were examined by Gram's staining test to differentiate between Gram positive and Gram negative bacteria using the procedure described by [13]. Potassium hydroxide test was carried out as a confirmatory test for Gram's iodine staining applying the procedure described by [14].

\subsection{Molecular Identification}

Isolates that showed growth with the different 
hydrocarbons were selected for identification through PCR amplification of $16 \mathrm{~S}$ rDNA. DNA extraction was carried out using phenol/chloroform/isoamylalcohol according to the procedure described by [15]. The quality of genomic DNA obtained was then analysed on $1 \%(\mathrm{w} / \mathrm{v})$ agarose gel in $1 \mathrm{X}$ TAE buffer.

An aliquot of genomic DNA extracted from each isolate was used as a template to amplify $16 \mathrm{~S}$ rDNA gene. The gene was amplified using two universal primers (Eurofins genomics, Germany): 16S F27, forward 5'...AGA GTT TGA TCC TGG CTC AG...3' and R1492, reverse 5'...GGT TAC CTT GTT ACG ACT T ...3' [16]. The PCR reaction was performed in PCR reaction tubes $(25 \mu \mathrm{l})$ using $12.5 \mu \mathrm{l}$ OneTaq ${ }^{\circledR}$ Quick-Load ${ }^{\circledR} 2 \mathrm{X}$ master mix with standard buffer (New England Biolabs, United States), nuclease free water $(9.5 \mu \mathrm{l}), 10 \mu \mathrm{M}$ forward primer $(0.5 \mu \mathrm{l}), 10 \mu \mathrm{M}$ reverse primer $(0.5 \mu \mathrm{l})$ and genomic DNA template $(2 \mu \mathrm{l})$. Thermocycler (MJ research - PTC 200, USA) was used and the conditions for the PCR were as follows: An initial denaturation step at $95^{\circ} \mathrm{C}$ for $3 \mathrm{~min}$ followed by 30 cycles of $95^{\circ} \mathrm{C}$ for $30 \mathrm{sec}, 52^{\circ} \mathrm{C}$ for $45 \mathrm{sec}$ and $68^{\circ} \mathrm{C}$ for $45 \mathrm{sec}$ and a final extension step at $68^{\circ} \mathrm{C}$ for 5 min followed by holding at $4^{\circ} \mathrm{C}$. A positive control (E. coli $16 \mathrm{~S}$ rDNA) and negative control (water) were included in gel electrophoresis of PCR products. The PCR amplicons were then purified using Qiaquick PCR purification kit (Qiagen, Valencia, USA) and sent to Eurofins Genomics Ebersberg Germany, for sequencing. Obtained sequences were analyzed and deposited in Genbank.

Obtained 16S rDNA sequences were compared with already known 16S rDNA sequences at National Center for Biotechnology Information (NCBI) database using BLAST (Basic Local Alignment Search Tool) algorithm. All the sequences were then aligned using CLUSTAL W algorithm in Geneoius 9.1.4 and Phylogenetic trees constructed based on the nucleotide sequences with the Bayesian phylogenetic method in MrBayes software. The trees were then visualized using Fig tree version 1.3.1 software.

\subsection{Biochemical Tests (Carbohydrate Fermentation, Starch Hydrolysis and Catalase Tests)}

Glucose, fructose, maltose, and sucrose fermentation tests were carried out using phenol red carbohydrate broth according to the method described by [17]. The procedure described by [18] was applied with some modification for starch hydrolysis test. In this test, pure bacterial colony from each isolate was streaked in a straight line on minimal media agar plate containing $2 \%$ soluble starch and incubated at $37^{\circ} \mathrm{C}$ for 48 hours. The catalase test was performed according to the procedure described by [19].

\subsection{Optimization of Growth Conditions for Diesel Oil Degrading Bacteria}

Optimization of growth conditions for three selected bacterial isolates was conducted using diesel oil according to the procedure described by [20] with some modifications.

\subsubsection{Effect of pH on Bacterial Growth During Biodegradation of Diesel Oil}

The effect of $\mathrm{pH}$ on growth of three bacterial strains was determined using $100 \mathrm{ml}$ BHM supplemented with $1 \%$ diesel oil as the sole carbon source. Bacterial inoculums $(100 \mu \mathrm{l})$ previously cultured overnight in LB media were inoculated in autoclaved BHM with $\mathrm{pH}$ values equating to 3, 5, 7, 9 and 11 following washing with $0.85 \% \mathrm{NaCl}$. The $\mathrm{pH}$ values were adjusted appropriately using $1 \mathrm{M} \mathrm{NaOH}$ and $1 \mathrm{M} \mathrm{HCl}$. The test was conducted at $37^{\circ} \mathrm{C}$ for 7 days in a shaker with a speed of $150 \mathrm{rpm}$. Control tests containing no bacterial inoculum were also included. Bacterial growth was then monitored using spectrophotometer readings at $600 \mathrm{~nm}$ and net dry biomass $\left(\mathrm{g} \mathrm{l}^{-1}\right)$ determined simultaneously. An aliquot $(5 \mathrm{ml})$ of culture media was pipetted into a pre-weighed centrifuge tube and spun at $16000 \mathrm{x} \mathrm{g}$ for $10 \mathrm{~min}$. This was then washed twice with distilled water and dried overnight at $90^{\circ} \mathrm{C}$ before reweighing and the difference in weight and the volume used considered to obtain dry biomass.

\subsubsection{Effect of Temperature on Bacterial Growth During Biodegradation of Diesel Oil}

The test was conducted using $1 \%$ substrate concentration at varying temperatures $\left(25^{\circ} \mathrm{C}, 30^{\circ} \mathrm{C}, 37^{\circ} \mathrm{C}, 45^{\circ} \mathrm{C}\right.$ and $\left.55^{\circ} \mathrm{C}\right)$ alongside control tests. Bacterial growth was determined after culturing for 7 days using spectrophotometer readings at $600 \mathrm{~nm}$ and the dry biomass $\left(\mathrm{g} \mathrm{l}^{-1}\right)$ also determined simultaneously as described in section 2.7.1.

\subsubsection{Effect of Various Concentrations of Diesel Oil on Bacterial Growth During Biodegradation}

The influence of substrate concentration on growth of the three bacterial isolates was determined using sterile BHM at pH 7 supplemented with various concentration of diesel oil i.e., $0.5,1,3$, and $5 \%$ at $37^{\circ} \mathrm{C}$. Bacterial growth was determined after culturing for 7 days in a shaker at $150 \mathrm{rpm}$. Growth was determined using spectrophotometer readings at $600 \mathrm{~nm}$ and the dry biomass $\left(\mathrm{g} \mathrm{l}^{-1}\right)$ determined simultaneously as described in section 2.7.1.

\subsubsection{Effect of Nitrogen Source on Bacterial Growth During Diesel Oil Biodegradation}

The influence of nitrogen source on growth of the three bacterial isolates was determined using autoclaved nitrogen-limited minimal media $(100 \mathrm{ml})$ supplemented with $1 \%$ diesel oil at $\mathrm{pH} 7$ and $37^{\circ} \mathrm{C}$. Ammonium nitrate $\left(\mathrm{NH}_{4} \mathrm{NO}_{3}\right)$, yeast extract and tryptone $[0.1 \%(\mathrm{w} / \mathrm{v})]$ were separately used as nitrogen sources. Bacterial growth was determined after culturing for 7 days in a shaker at 150 rpm using spectrophotometer readings at $600 \mathrm{~nm}$ and the dry biomass $\left(\mathrm{g} \mathrm{l}^{-1}\right)$ determined simultaneously as described in section 2.7.1.

Statistical analysis

All analyses were carried out in triplicate and the experimental data analyzed using one way Analysis of variance (ANOVA) using Statistical Package for Social Sciences (SPSS), version 19.0 [21,22]. Differences among mean values for treatments at $\mathrm{P}<0.05$ were evaluated using 
Post hoc test (Tukey's test).

\subsection{Hydrocarbon analysis using GC-MS}

Diesel oil in BHM inoculated with isolates 1C, 2C, 3A and 4A2 were analyzed after 21 days of incubation. An aliquot $(100 \mu \mathrm{l})$ of bacterial cells was transferred to a $250 \mathrm{ml}$ volumetric flask containing $100 \mathrm{ml}$ sterile BHM supplemented with $1 \%$ diesel oil. Un-inoculated BHM flask was kept as a control. After 21 days of incubation, the hydrocarbons were analyzed according to the procedure described by [23] with some modifications. Hydrocarbon extraction from $30 \mathrm{ml}$ BHM was done using an equal volume of dichloromethane on a separating funnel. This was repeated twice to ensure complete recovery of the hydrocarbons. The dichloromethane phases were then combined and treated with anhydrous $\mathrm{Na}_{2} \mathrm{SO}_{4}$ to remove emulsions and residual water. The resultant extracts were concentrated by evaporation under a stream of Nitrogen using a heidolph rotary evaporator (Goel Scientific, India). The residue obtained from each sample was then re-dissolved in dichloromethane. Hydrocarbon composition was analyzed by GC-MS using Shimadzu QP2010SE series GC-MS (Shimadzu, Japan) equipped with Zebron GC column (ZB-1MS) [30.0 m by $0.25 \mathrm{~mm}$ (inner diameter)] with a thickness of $0.50 \mu \mathrm{m}$. Helium was used as the carrier gas and a temperature program consisting of an initial oven temperature of $55^{\circ} \mathrm{C}$ for 3 minutes increased to $245^{\circ} \mathrm{C}$ for $5 \mathrm{~min}$ at a rate of $4^{\circ} \mathrm{C} / \mathrm{min}$. An aliquot of $10 \mu \mathrm{l}$ was used as the sample. The injector and detector temperatures were maintained at $250^{\circ} \mathrm{C}$ and $260^{\circ} \mathrm{C}$ respectively.

\subsection{Alkane hydroxylase Gene Amplification}

An aliquot $(2 \mu \mathrm{l})$ of genomic DNA extracted from three selected isolates was used as a template to amplify alkB gene. The gene was amplified using two primers (Eurofins genomics, Germany): alk-3F (5'... TCG AGC ACA TCC GCG GCC ACC A...3') and alk-3R (5'...CCG TAG TGC TCG ACG TAG TT...3') [3]. The expected PCR poduct was $330 \mathrm{bp}$. The process was performed in PCR tubes $(25$ $\mu 1)$ by adding OneTaq ${ }^{\circledR}$ Quick-Load ${ }^{\circledR} 2 \mathrm{X}$ master mix with standard buffer $(12.5 \mu \mathrm{l})$, nuclease free water $(9.5 \mu \mathrm{l}), 10$ $\mu \mathrm{M}$ forward primer $(0.5 \mu \mathrm{l}), 10 \mu \mathrm{M}$ reverse primer $(0.5$ $\mu 1)$ and genomic DNA template $(2 \mu 1)$. Thermocycler conditions for the PCR were as follows: An initial denaturation step at $94^{\circ} \mathrm{C}$ for $2 \mathrm{~min}$ followed by 30 cycles of $94^{\circ} \mathrm{C}$ for $1 \mathrm{~min}, 54^{\circ} \mathrm{C}$ for $30 \mathrm{sec}$ and $72^{\circ} \mathrm{C}$ for $30 \mathrm{sec}$ and a final primer extension step at $72^{\circ} \mathrm{C}$ for $5 \mathrm{~min}$ and a final hold at $4^{\circ} \mathrm{C}$. PCR products obtained were electrophoresed alongside GeneRuler $1 \mathrm{~kb}$ DNA ladder (ThermoFisher Scientific, USA) on a $1 \%$ agarose gel with $1 \mathrm{X}$ TAE buffer and visualized under a UV light transilluminator before purification using Qiaquick PCR purification kit and sent to Eurofins Genomics Ebersberg, Germany for sequencing. Phylogenetic analysis was then carried out as previously described for $16 \mathrm{~S}$ rDNA in section 2.5 .

\section{Results}

\subsection{Bacteria Isolation}

Twenty bacterial isolates and a fungal isolate were obtained following isolation and purification. These were denoted as $1 \mathrm{C}, 2 \mathrm{C}, 3 \mathrm{C}, 4 \mathrm{C}, 5 \mathrm{C}, 5 \mathrm{CB}, 6 \mathrm{C}, 1 \mathrm{~B}, 2 \mathrm{~B}, 3 \mathrm{~B}, 4 \mathrm{~B}$, $5 \mathrm{~B}, 6 \mathrm{~B}, 1 \mathrm{~A}, 2 \mathrm{~A}, 3 \mathrm{~A}, 4 \mathrm{~A}, 4 \mathrm{~A} 2,5 \mathrm{~A}, 6 \mathrm{~A}$ and $3 \mathrm{AF}$ (fungi) based on the sampling locations. Six sites $(1-6)$ were sampled at three different soil depths \{surface $(1 \mathrm{~cm})$, sub-surface $1(5$ $\mathrm{cm})$ and sub-surface $2(15 \mathrm{~cm})$ denoted as $\mathrm{C}, \mathrm{B} \& \mathrm{~A}$ respectively\}.

\subsection{Screening for Biodegradation Potential}

Following isolation, selection of efficient hydrocarbon degraders based on the ability to grow in minimal media supplemented with heating oil was done. All the isolates grew. Isolates $4 \mathrm{~A} 2,3 \mathrm{~A}, 5 \mathrm{~A}, 6 \mathrm{~A}, 1 \mathrm{~B}, 1 \mathrm{C}, 2 \mathrm{C}, 5 \mathrm{C}$ and $6 \mathrm{C}$ showed steady increase in cell density compared to the rest of the isolates and were therefore selected for further studies (Figure 1). Screening for degradation of single hydrocarbons was carried out by exposing isolates cultured in BHA plates to toluene, hexane and octane vapors and the results are shown in Table 1.

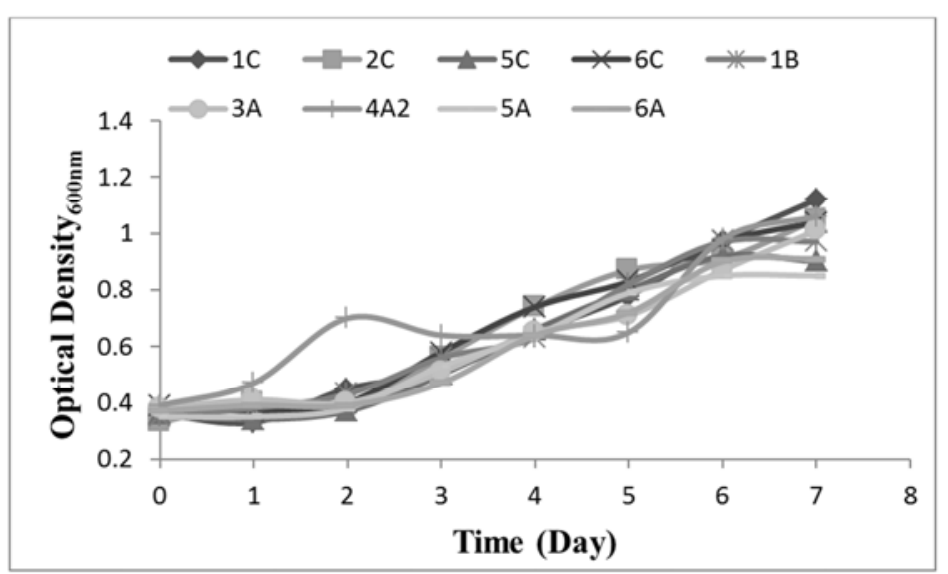

Figure 1. Time course of growth for bacterial isolates cultured in minimal media supplemented with $1 \%$ heating oil for 7 days. 
Table 1. Growth of isolates cultured in BHA plates exposed to toluene, hexane and octane hydrocarbons after 14 days of incubation at $25^{\circ} \mathrm{C}$.

\begin{tabular}{llll}
\hline Isolate & $\mathbf{1 0 \%}$ Toluene $+\mathbf{9 0 \%}$ Hexadecane & $\mathbf{2 0 \%}$ Hexane $+\mathbf{8 0} \%$ Hexadecane & $\mathbf{2 0 \%}$ Octane + $\mathbf{8 0} \%$ Hexadecane \\
\hline 1C & - & + & + \\
$2 \mathrm{C}$ & - & + & - \\
$5 \mathrm{C}$ & - & + & - \\
$6 \mathrm{C}$ & - & - & - \\
$1 \mathrm{~B}$ & - & + & + \\
$3 \mathrm{~A}$ & - & + & + \\
$4 \mathrm{~A} 2$ & + & - & - \\
$5 \mathrm{~A}$ & - & - & - \\
$6 \mathrm{~A}$ & - & & \\
\hline
\end{tabular}

+ denotes growth, - denotes no growth

\subsection{Morphological and Molecular Identification of Isolates}

Table 2 shows Gram's stain and $\mathrm{KOH}$ test results of some of the selected isolates. Variation in morphological characteristics of the colonies suggests that the selected isolates were different from each other. Figure 2 shows a gel photograph of $16 \mathrm{~S}$ rDNA PCR amplicons $(\approx 1500$ bp DNA fragments) of the nine selected bacterial isolates. A phylogenetic tree based on the BLAST search was constructed and the topological robustness of the tree evaluated using percentages of posterior probabilities as shown in Figure 3.

Table 2. Morphological characteristics of selected oil degrading bacteria cultured on LB agar plates.

\begin{tabular}{lllllll}
\hline & \multicolumn{2}{l}{ Colony Characteristics } & \multicolumn{3}{l}{ Gram's staining and KOH tests } \\
\hline Isolate & Colony forms & Color of colonies & Margin & Gram's iodine staining & KOH Test & Shape of cells \\
\hline 1C & Irregular & Pale brown & Undulate & - & + & + \\
2C & Circular & Cream white & Entire & - & + & Rods \\
5C & Irregular & Cream yellow & Lobate & - & + & Cocci \\
6C & Circular & White & Curled & - & + & Cocci \\
1B & Irregular & Cream white & Undulate & - & + & Cocci \\
3A & Circular & Cream white & Undulate & - & + & Cocci \\
4A2 & Irregular & Yellow & Lobate & - & + & Cocci \\
5A & Irregular & Cream & Undulate & - & + & Cocci \\
6A & Irregular & Cream & Curled & - & + & Cocci \\
\hline
\end{tabular}

+ denotes positive test, - denotes negative test

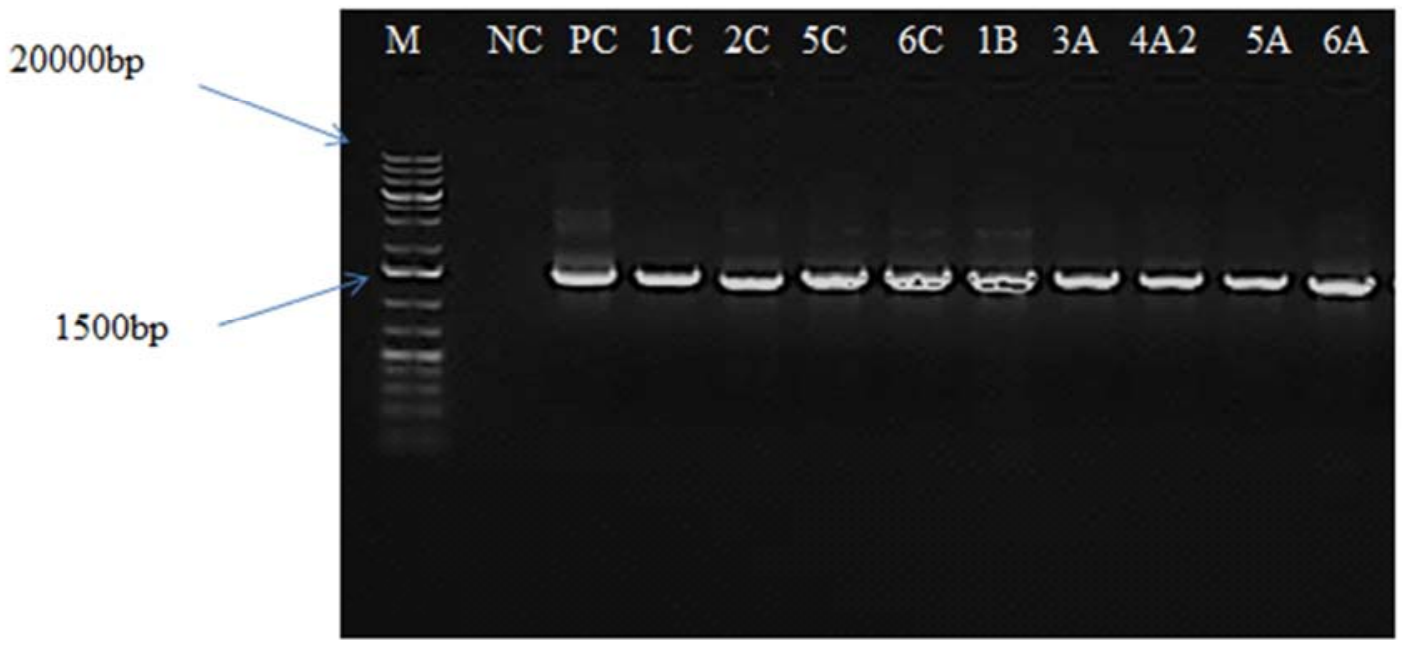

Figure 2. Gel photograph of $16 \mathrm{~S} r D N A$ PCR amplicons for isolates $2 C, 1 C, 5 C, 6 C, 1 B, 3 A, 4 A 2,5 A$ and $6 A$. M is the molecular marker (GeneRuler $1 \mathrm{~kb}$ plus, ThermoFisher Scientific, USA), NC is the negative control while PC is the positive control (E. coli).

The nine bacterial isolates clustered with members of the following genera; Pseudomonas, Acinetobacter, Ochrobactrum, Salmonella, Enterobacter and Klebsiella. Closest relatives to these isolates together with their percentage identity as obtained from the BLAST search at the NCBI database is as shown in Table 3. The sequences were deposited in NCBI Genbank and awarded accession numbers as indicated in the table. 


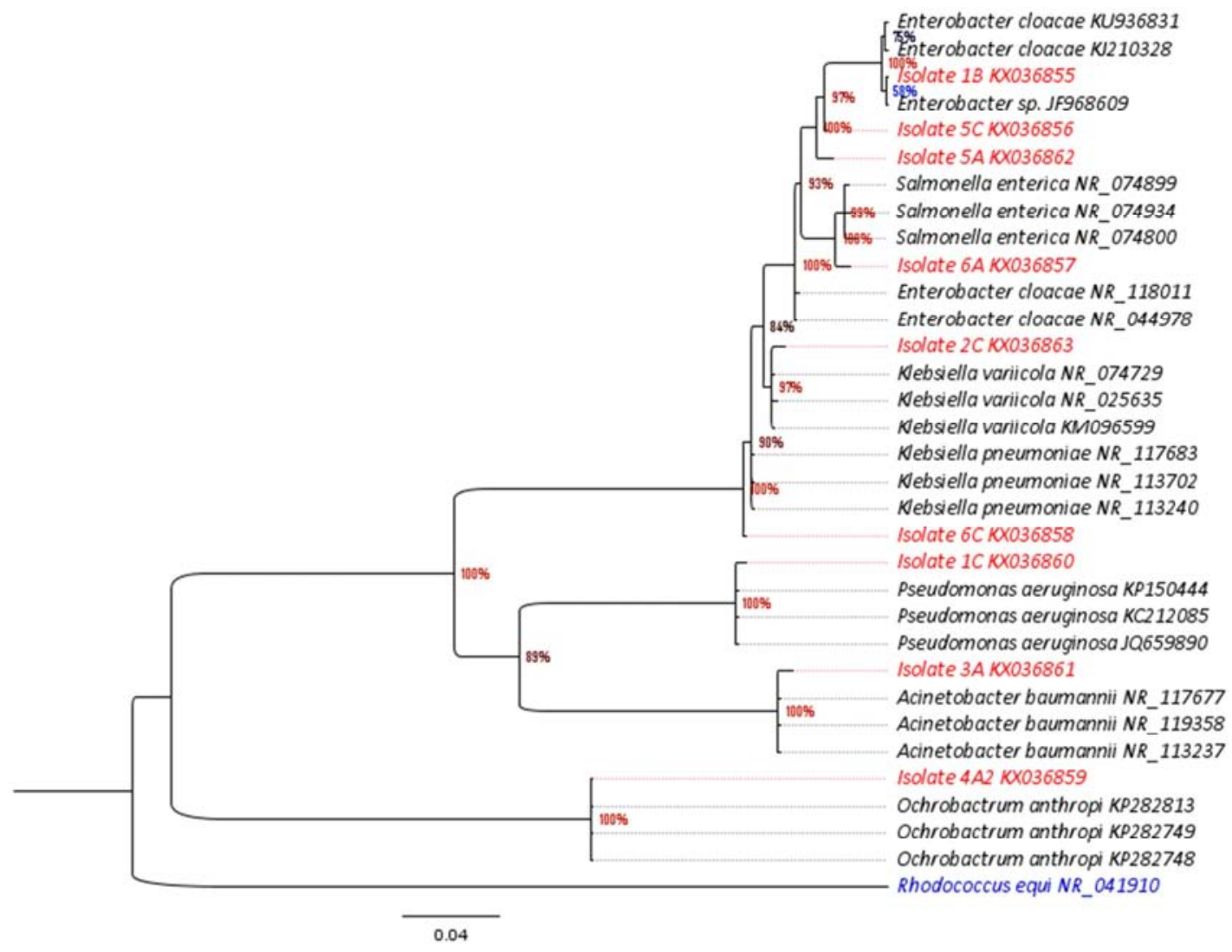

Figure 3. Phylogenetic tree based on $16 \mathrm{~S}$ rDNA gene sequences. The tree was constructed using comparable $16 \mathrm{~S}$ rDNA gene sequences of isolates from the current study and those retrieved from the NCBI database. The numbers at the node indicate bootstrap values as percentages obtained with 1000 resampling analyses. Branch length unit is the number of substitutions per nucleotide position. Isolates from the current study are shown in red. The tree is rooted using $16 S$ rDNA sequence from Rhodococcus equi (shown in blue).

Table 3. Closest relatives of selected bacteria based on $16 \mathrm{~S}$ rDNA gene sequences.

\begin{tabular}{lllll}
\hline Isolate & Closest hit & Phylum: Proteobacteria & Accession number & Identity (\%) \\
\hline 1C & Pseudomonas aeruginosa & Gammaproteobacteria & KX036860 & 99 \\
2C & Klebsiella variicola & Gammaproteobacteria & KX036863 & 99 \\
5C & Enterobacter cloacae & Gammaproteobacteria & KX036856 & 99 \\
6C & Klebsiella pneumoniae & Gammaproteobacteria & KX036858 & 99 \\
1B & Enterobacter cloacae & Gammaproteobacteria & KX036855 & 99 \\
3A & Acinetobacter baumannii & Gammaproteobacteria & KX036861 & 99 \\
4A2 & Ochrobactrum anthropi & Alphaproteobacteria & KX036859 & 99 \\
5A & Enterobacter cloacae & Gammaproteobacteria & KX036862 & 99 \\
6A & Salmonella enterica & Gammaproteobacteria & KX036857 & 99 \\
\hline
\end{tabular}

\subsection{Biochemical Characterization}

A summary of the carbohydrate fermentation, catalase, and starch hydrolysis tests is given in Table 4 below.

Table 4. Biochemical characteristics of the nine selected bacterial isolates.

\begin{tabular}{|c|c|c|c|c|c|c|c|}
\hline \multirow{2}{*}{ Isolate } & \multicolumn{5}{|c|}{ Carbohydrate fermentation test } & \multirow{2}{*}{ Catalase test } & \multirow{2}{*}{ Starch test } \\
\hline & Glucose & Fructose & Maltose & Sucrose & Gas production & & \\
\hline $1 \mathrm{C}$ & - & - & - & - & - & + & - \\
\hline $2 \mathrm{C}$ & + & + & + & + & + & + & - \\
\hline $5 \mathrm{C}$ & + & + & + & + & + & + & - \\
\hline $6 \mathrm{C}$ & + & + & + & + & - & + & - \\
\hline 1B & + & + & + & + & - & + & - \\
\hline $3 \mathrm{~A}$ & - & - & - & - & - & + & - \\
\hline $5 \mathrm{~A}$ & + & + & + & + & + & + & - \\
\hline $6 \mathrm{~A}$ & + & + & + & + & - & + & - \\
\hline
\end{tabular}

+ denotes positive test, - denotes negative test 


\subsection{Optimization of Growth Conditions for Diesel Oil Degrading Bacteria}

There was significant difference in diesel oil degradation depicted by microbial growth at the different $\mathrm{pH}$ values $(\mathrm{p}<0.05)$. Post hoc test was carried out using Tukey's test at a significance level of 0.05 . The optimum $\mathrm{pH}$ for microbial growth was 7 (Figure 4). At this $\mathrm{pH}$, maximum biomass obtained was $0.594 \mathrm{~g} \mathrm{l}^{-1}, 0.742 \mathrm{~g} \mathrm{l}^{-1}$ and $0.609 \mathrm{~g} \mathrm{l}^{-1}$ for isolate $3 \mathrm{~A}, 1 \mathrm{C}$ and $2 \mathrm{C}$ respectively. Below and above $\mathrm{pH} 7$, growth of the three isolates was reduced. Isolate $3 \mathrm{~A}$ however, showed slight tolerance to alkaline $\mathrm{pH}$ compared to isolate $2 \mathrm{C}$ during the growth period.

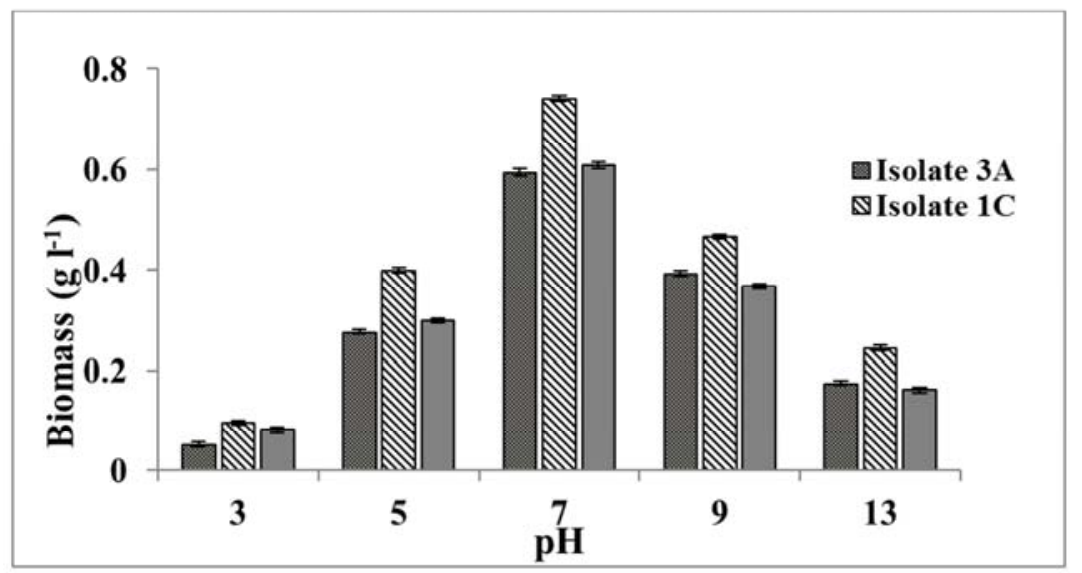

Figure 4. Effect of $\mathrm{pH}$ on growth of the three selected isolates. Bacterial growth expressed in biomass $\left(\mathrm{g} \mathrm{l}^{1}\right)$ after 7 days of incubation using BHM supplemented with $1 \%$ diesel oil. Error bars have been displayed using standard error of the mean. Microbial growth was optimal at pH 7.

To determine the influence of temperature on diesel oil degradation by the three selected isolates, growth was carried out at temperatures ranging from $25^{\circ} \mathrm{C}$ to $55^{\circ} \mathrm{C}$ and at the predetermined optimum $\mathrm{pH}$ (Figure 5). There was a significant variation in microbial growth at $25^{\circ} \mathrm{C}, 37^{\circ} \mathrm{C}$ and $55^{\circ} \mathrm{C}(\mathrm{p}<0.05)$. However, there was no significant difference in growth at $25^{\circ} \mathrm{C}$ and $45^{\circ} \mathrm{C}(\mathrm{P}=0.153)$ and at $30^{\circ} \mathrm{C}$ and $37^{\circ} \mathrm{C}(\mathrm{P}=0.515)$. From these results, it is evident that a temperature range of between $30^{\circ} \mathrm{C}$ and $37^{\circ} \mathrm{C}$ is suitable for growth of the three selected bacterial isolates $(1 \mathrm{C}, 2 \mathrm{C}$ and 3A). Maximum biomass was obtained at $37^{\circ} \mathrm{C}$.

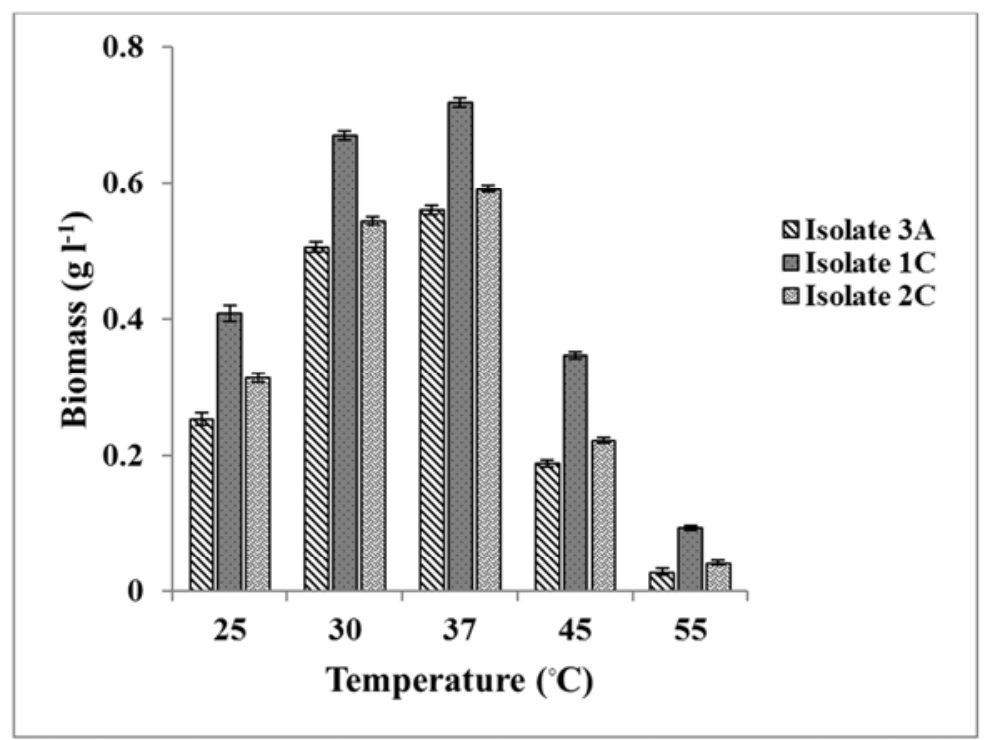

Figure 5. Effect of temperature on diesel oil degradation expressed in biomass $\left(g l^{-1}\right)$ after 7 days of incubation at $p H 7$. Error bars have been displayed using the standard error of the mean. Optimum temperature for diesel oil biodegradation indicated by microbial growth was recorded at $37^{\circ} \mathrm{C}$ for all the three isolates.

Microbial growth decreased with increase in diesel oil concentration as shown in Figure 6. There was a significant difference in bacterial growth at diesel oil concentrations of $0.5 \%, 1 \%, 3 \%$ and $5 \%(\mathrm{P}=0.000)$. Notably, maximum biomass at $0.5 \%$ diesel oil concentration was obtained earlier (on the $4^{\text {th }}$ day) during the culturing period compared to the rest of the increased diesel oil concentrations for all the three isolates. At $0.5 \%$ diesel oil concentration, maximum biomass obtained for isolate $3 \mathrm{~A}, 1 \mathrm{C}$ and $2 \mathrm{C}$ were $0.757 \mathrm{~g} / \mathrm{L}, 0.885 \mathrm{~g} / \mathrm{L}$ and $0.7843 \mathrm{~g} / \mathrm{L}$ respectively. 


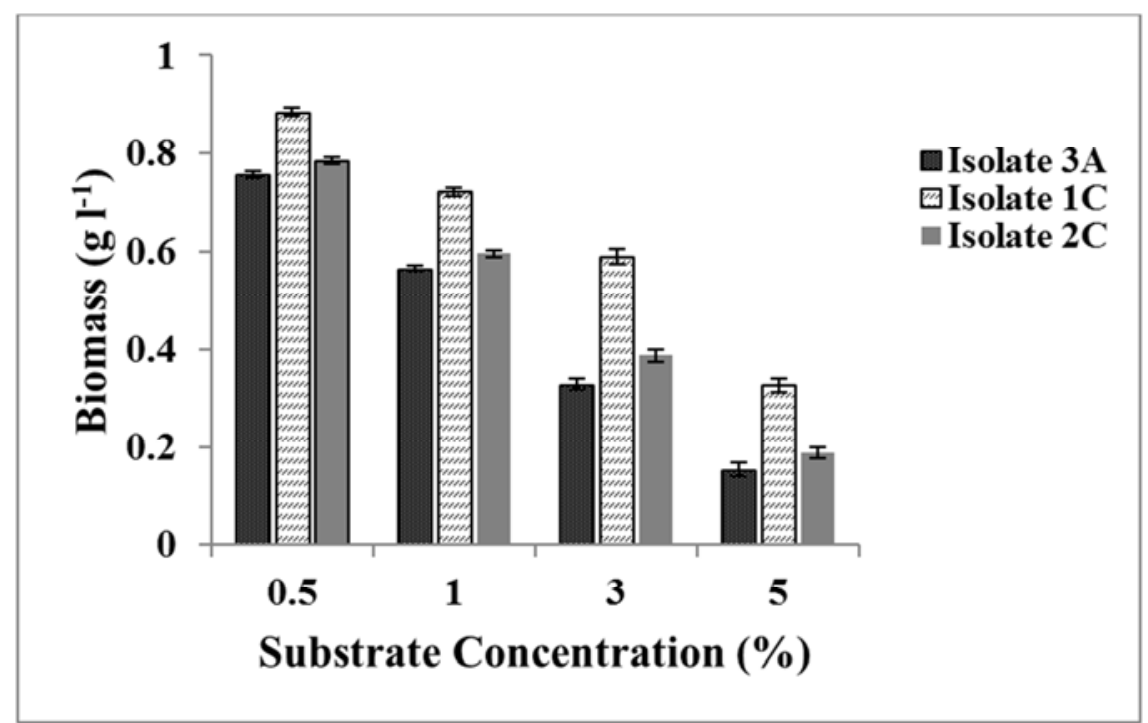

Figure 6. Effect of substrate concentration (diesel oil) on microbial growth in biomass ( $g l^{-1}$ ) after 7 days of incubation at $37^{\circ} \mathrm{C}$. Error bars have been displayed using standard error of the mean. Optimum growth was recorded at diesel oil concentration of $0.5 \%$.

The effect of nitrogen source on diesel oil degradation by isolates $1 \mathrm{C}, 2 \mathrm{C}$ and $3 \mathrm{~A}$ is presented in Figure 7. Ammonium nitrate, yeast extract and tryptone were separately used as nitrogen sources at the predetermined optimal $\mathrm{pH}$ and temperature. Significant variation in microbial growth was observed for the three nitrogen sources $(p<0.05)$. From these results, microbial growth was highest in presence of yeast extract. With yeast extract, maximum biomass obtained was $1.344 \mathrm{~g} / \mathrm{L}, 1.163 \mathrm{~g} / \mathrm{L}$ and $0.972 \mathrm{~g} / \mathrm{L}$ for isolate $3 \mathrm{~A}, 1 \mathrm{C}$ and $2 \mathrm{C}$ respectively.

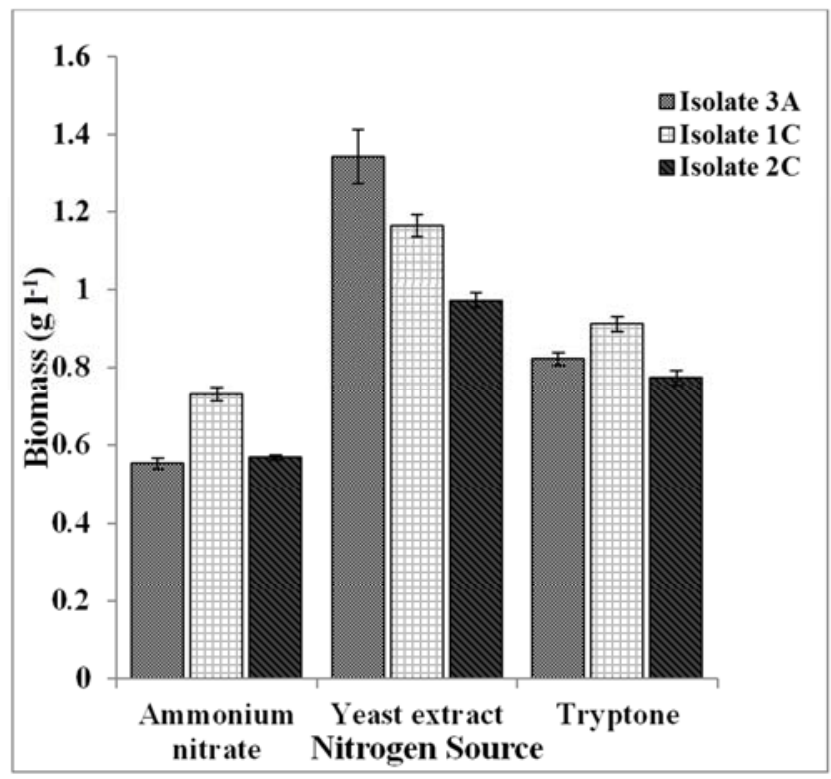

Figure 7. Effect of nitrogen source on microbial growth during diesel oil degradation. Growth expressed in terms of biomass $\left(g l^{-1}\right)$ after 7 days of incubation at $\mathrm{pH} 7$ and at $37^{\circ} \mathrm{C}$. Error bars have been displayed using standard error of the mean. For all the three isolates, microbial growth was highest using yeast extract as the nitrogen source followed by tryptone and ammonium nitrate respectively.

\subsection{Analysis of Diesel oil Degradation by Gas Chromatography-Mass Spectrometry (GC-MS)}

The data obtained shows that the isolates were capable of readily mineralizing most of the hydrocarbons present in diesel oil. This is indicated by decrease in size of hydrocarbon peaks (low relative abundance) at certain retention times (Figure 8). Comparison of chromatogram profiles of the control and the different isolates indicate that most of the branched chain and cyclic alkanes as well as aromatic hydrocarbons were completely degraded as is indicated by absent peaks. In contrast, peaks for linear alkanes were still present though at reduced amplitudes. New peaks indicating formation of metabolic intermediates were also observed. Mono-aromatics (such as Benzene, 1,2,3trimethyl- and 5-Ethyl-m-xylene) and polycyclic aromatic hydrocarbons (such as Naphthalene, 2-ethyldecahydro- and Naphthalene, 1,2,3,4-tetrahydro-2,5,8-trimethyl-) were completely degraded by all the four isolates. Most branched chain alkanes (such as Decane, 2-methyl- and Eicosane, 2,4dimethyl-) were also completely depleted. With the exception of Cyclohexane, (4-methylpentyl)-, the isolates were also able to completely degrade cycloalkanes present in diesel oil. Conversely, almost all linear alkanes were still present at the end of the incubation period though at reduced levels. Isoprenoid hydrocarbons, phytane (hexadecane, 2,6,10,14tetramethyl) and pristine (pentadecane, 2,6,10,14tetramethyl) were also not completely depleted. 

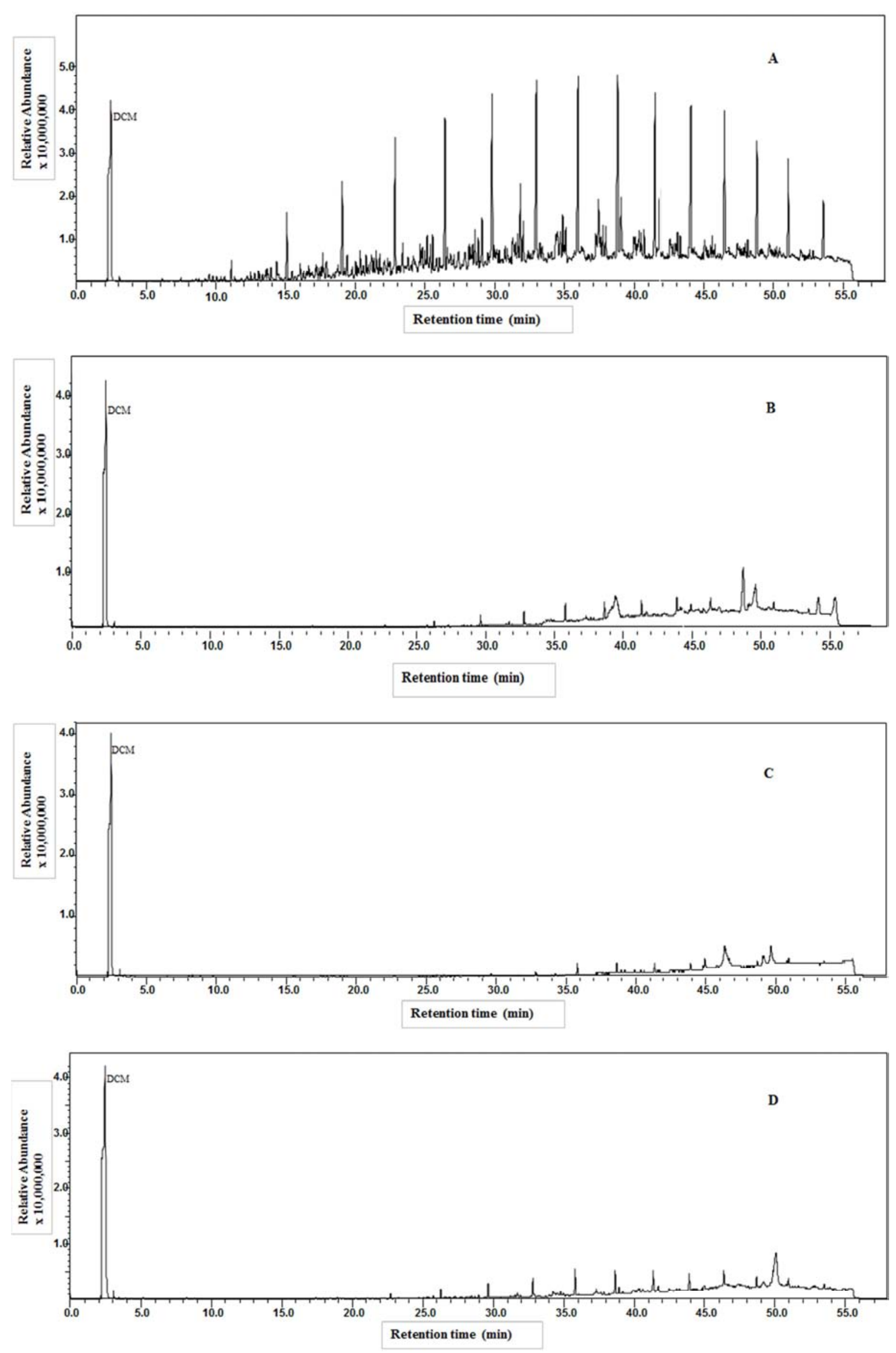


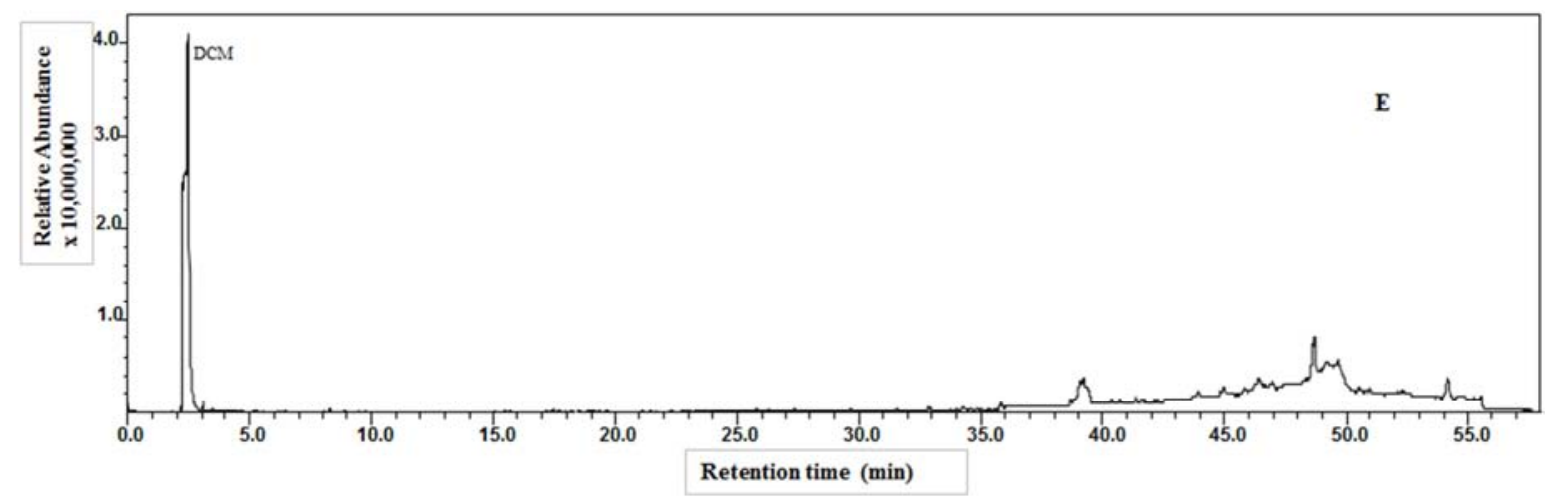

Figure 8. GC-MS profiles of diesel oil extracted from BHM after 21 days of incubation at $p H 7$ and $37^{\circ} \mathrm{C}$ with and without inoculation. (A) Control (uninoculated); (B) Isolate 1C; (C) Isolate 2C; (D) Isolate $3 A$ and (E) Isolate 4A2. Hydrocarbon and metabolite peaks were identified through comparison of retention times with mass spectrophotometer database using Autochro-3000 software. Diesel oil extraction was performed twice using dichloromethane (DCM) as the solvent.

\subsection{AlkB Gene PCR Amplification}

AlkB (Alkane hydroxylase) gene from genomic DNA of isolate 1C was amplified and sequenced. A PCR amplicon of $313 \mathrm{bp}$ was obtained. PCR amplification of the gene was however unsuccessful for isolates $2 \mathrm{C}$ and $3 \mathrm{~A}$. Obtained sequences were compared with already known alkB gene sequences at the NCBI database using BLAST algorithm.
The sequence was deposited at the NCBI database under the accession number, KX036864. A phylogenetic tree was constructed using sequences from BLAST search and the isolate's alkB sequence. The topological robustness of the tree was evaluated using percentages of posterior probabilities. Figure 9 shows the phylogenetic tree for alkB gene sequences constructed using MrBayes software.

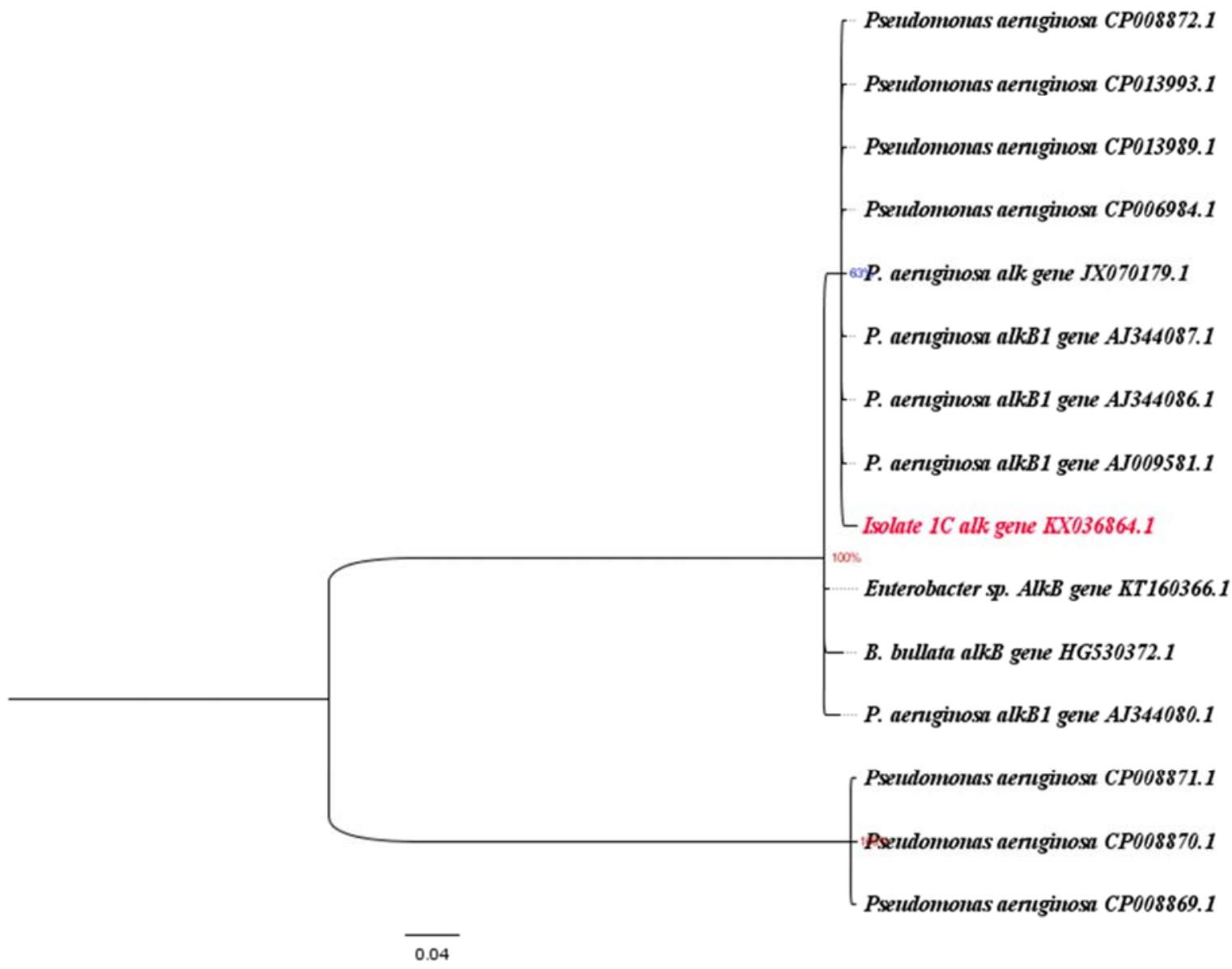

Figure 9. Phylogenetic relationship of isolate $1 C$ alkB gene (shown in red) with alkB gene of 14 closely related bacterial strains from NCBI database. The tree is rooted at mid-point. The numbers at the node show bootstrap values as percentages obtained with 1000 resampling analyses. Branch length unit (0.04) represents the number of substitutions per nucleotide site. 


\section{Discussion}

Increased oil explorations in the East African region and the anticipated oil spillages that do occur during routine operations and transportation have raised concerns of environment pollution [24]. In the present study, hydrocarbon degraders were isolated from auto garage contaminated soils from Ngara region in Nairobi-Kenya. A total of 20 bacterial and 1 fungal isolates were obtained from the oilcontaminated soils sampled. Nine isolates were selected for further studies and these exhibited variable morphological characteristics as shown in Table 2.

\subsection{Screening for Hydrocarbon Degradation}

During culturing in heating oil, isolates $3 \mathrm{~A}, 5 \mathrm{~A}, 6 \mathrm{~A}, 1 \mathrm{~B}$, $1 \mathrm{C}, 2 \mathrm{C}, 5 \mathrm{C}, 6 \mathrm{C}$ and $4 \mathrm{~A} 2$ demonstrated high growth as indicated by increase in optical density readings at $600 \mathrm{~nm}$. Post hoc analysis (Tukey) showed that there was no significant difference in microbial growth of all isolates up to day $2(p>0.05)$ as evidenced in the growth curves (Figure 1). This was probably due to unavailability of enzymes (before induction) involved in mineralization of the complex hydrocarbons and/or minimal production of secondary metabolites important for microbial growth [3]. Significant growth $(\mathrm{p}<0.05)$ was later noted on subsequent days after which growth remained fairly constant after the $7^{\text {th }}$ day. This stationary phase may be attributed to the need by the cell to adapt continuously to more complex hydrocarbons, depletion of degradable substrates or accumulation of waste products. For isolate $4 \mathrm{~A} 2$, the curve indicated a diauxic growth. For this isolate, the first stage of growth was observed between the first and second day of incubation in which simple hydrocarbons such as n-alkanes and some alkylic chains are possibly degraded. A stationary phase was then observed between the $3 \mathrm{rd}$ and 5 th day and later a second exponential phase noted after the 5 th day. More complex hydrocarbon molecules such as mono and poly aromatics are thought to be degraded during this phase. The ability of the bacterial isolates to utilize single hydrocarbons (hexane, octane and toluene) as carbon sources was evaluated. Results (Table 1) showed that isolate $4 \mathrm{~A} 2$ was able to utilize all the three hydrocarbons. Bacterial strains $1 \mathrm{C}, 2 \mathrm{C}, 6 \mathrm{C}, 3 \mathrm{~A}$ and $4 \mathrm{~A} 2$ on the other hand were able to utilize hexane while only $1 \mathrm{C}, 3 \mathrm{~A}$ and 4A2 could grow on octane. Only isolate 4A2 could grow on plates exposed to toluene indicating its ability to withstand toluene toxicity. Toluene is an aromatic hydrocarbon of the BTEX compounds (Benzine, Toluene, Ethylbenzene \& Xylene), which are classified as priority pollutants.

\subsection{Microbial Identification and Characterization}

Gram staining and potassium hydroxide tests revealed that majority of the isolates in this study were gram negative cocci-shaped with a few gram-negative rods (Table 2), a finding that is in agreement with other studies. Dominance of Gram negative bacteria in oil contaminated sites has been attributed to their lipopolysaccharide membrane which can play the role of a biosurfactant accelerating the biodegradation process [25]. PCR amplification of 16S rDNA gene (Figure 2) as well as sequencing revealed that the nine isolates belong to six different genera. From the tree topology (Figure 3), isolates 1B, 5A and 5C clustered with members of the genus Enterobacter while $2 \mathrm{C}$ and $6 \mathrm{C}$ clustered with members of the genus Klebsiella. Isolate $1 \mathrm{C}$ was found to be a member of the genus Pseudomonas while 3A, 4A2 and 6A clustered with members of the genus Acinetobacter, Ochrobactrum and Salmonella respectively. All these strains fall under the phylum proteobacteria with Ochrobactrum being an alpha proteobacteria while the rest are gamma proteobacteria (Table 3) as depicted also by clustering in the phylogenetic tree. Bacterial strains of subphyla $\alpha-, \beta$ - and $\gamma$ proteobacteria are well established in their ability to degrade a wide variety of hydrocarbons [16,25].

As expected, all the isolates in this study were found to possess catalase enzyme activity since they were isolated from oxygenated environment (soil) where they are required to neutralize toxic oxygen compounds (Table 4). This implies that the isolates are either aerobic or facultatively anaerobic [26]. Some of the isolates were capable of fermenting the different carbohydrates tested while some were found to be non-fermenters. Carbohydrate fermenting microbes are essential in the oil industry as some have been reported to produce biosurfactants which find applications in biodegradation of petroleum wastes as well as in oil recovery.

\subsection{Selected Hydrocarbon Degraders}

Isolate 1C, identified as Pseudomonas aeruginosa was capable of utilizing heating oil, hexane, octane as well as diesel oil as the sole carbon source. Members of the genus Pseudomonas have been identified as the most predominant group in metabolism of hydrocarbons [27]. Ability of Pseudomonas to efficiently take up alkanes has been linked to production of rhamnolipid biosurfactants as was demonstrated by [27] using $P$. aeruginosa DSVP20. This class of bacteria possesses a broad array of physiological and metabolic properties as well as a complex enzymatic system that enable them to utilize a wide range of aliphatic and aromatic compounds as their sole carbon source [4,27]. The metabolic versatility of Pseudomonas has been linked to presence of degradative plasmids such as OCT (octane), ALK (alkanes), TOL (toluene) XYL (xylene) and NAH (naphthalene) [28].

Two of the isolates (2C and $6 \mathrm{C}$ ) that demonstrated excellent growth when cultured in heating oil belonged to the genus Klebsiella. The two were also capable of utilizing hexane vapour as well as diesel oil as the sole carbon source. Klebsiella species are well established in degradation of petroleum compounds. Among 45 hydrocarbon degrading isolates obtained from estuary sediments, [29] reported that bacteria of the genus Klebsiella were the most frequently encountered (46.7\%) with some of them recording over $90 \%$ 
degradation of toluene, xylene, nonane and naphthalene.

In the current study, isolate $3 \mathrm{~A}$, identified as Acinetobacter baumannii was found to utilize heating oil, diesel oil, as well as hexane and octane vapors as the sole carbon source. In a study conducted by [25], Acinetobacter species was found to be the most abundant group. Efficiency of Acinetobacter sp. in utilization of hydrocarbons could be attributed to their ability to produce biosurfactants as was observed in a study conducted by [30]. In this study, A. radioresistens KA53 was reported to produce alasan which is a high-molecular-weight bioemulsifier complex observed to accelerate mineralization of recalcitrant polycyclic aromatic hydrocarbons (PAHs) [30].

\subsection{Determination of Optimum Conditions for Growth Using Diesel Oil}

In the present study, an optimum $\mathrm{pH}$ of 7 was observed for all the three selected isolates. Isolate $1 \mathrm{C}$ however, displayed higher biomass production $\left(0.742 \mathrm{~g} \mathrm{l}^{-1}\right)$ compared to the other two isolates (Figure 4). A number of studies have also indicated optimal growth at or near $\mathrm{pH} 7$ [20,31,32]. Maintenance of an optimal $\mathrm{pH}$ condition is very vital as variation in $\mathrm{pH}$ of the culture media caused by accumulation of metabolic waste products affects microbial growth [32]. Notably, Isolate $3 \mathrm{~A}$ was slightly tolerant to alkaline $\mathrm{pH}$ compared to isolate $2 \mathrm{C}$. This could be linked to soil $\mathrm{pH}$ where the isolate was sampled. Isolate $2 \mathrm{C}$ was isolated from the surface compared to isolate $3 \mathrm{~A}$ from the sub surface 2, much deeper than the former. It has been reported that for oil contaminated soils, as soil depth increases, the $\mathrm{pH}$ value also increases [31].

The three bacterial strains were observed to grow well at $30^{\circ} \mathrm{C}$ and $37^{\circ} \mathrm{C}(\mathrm{p}<0.05)$. At $37^{\circ} \mathrm{C}$ however, a higher microbial biomass was noted for all the three strains with isolate $1 \mathrm{C}$ again recording the highest biomass $\left(0.718 \mathrm{~g} \mathrm{l}^{-1}\right)$ indicating greater diesel oil utilization (Figure 5). Above $37^{\circ} \mathrm{C}$, growth was reduced. Though the optimum temperature was found to be $37^{\circ} \mathrm{C}$, P. aeruginosa AT18 strain was found to efficiently assimilate n-alkanes, naphthalene, toluene and crude oil at $41^{\circ} \mathrm{C}$ in a study conducted by [28].

In the current study, optimization of diesel oil concentration revealed that $0.5 \%$ substrate concentration provided excellent growth for the three isolates (Figure 6). A suitable range of diesel oil concentration was observed between $0.5-1 \%$ although isolate $1 \mathrm{C}$ was able to tolerate up to $3 \%$ diesel oil concentration. This is similar to a study conducted by [32] in which Pseudomonas and Bacillus species were observed to tolerate increased diesel oil concentration. Thus an optimum range of substrate concentration is very vital since biodegradation is not easily stimulated below the oil concentration range while above the range, growth inhibition may occur due to oxygen limitations as well as solvent toxic effect.

Significant difference in microbial growth was observed for the three nitrogen sources with the addition of yeast extract giving the highest growth among the three isolates (Figure 7). This is in agreement with a study performed by
[31] in which Pseudomonas aeruginosa, Pseudomonas putida, Aeromonas hydrophila and Acinetobacter lwoffii were observed to grow optimally using yeast extract and tryptone as the nitrogen source. Although yeast extract was observed to provide excellent microbial growth as a nitrogen source in the present study, growth was also observed for ammonium nitrate as nitrate possess high oxidation potential for elimination of hydrocarbon contaminants which normally exist in a reduced state [12].

\subsection{GC-MS Analysis of Diesel Oil Degradation}

Compared to straight chain alkanes, most branched-chain and cyclic alkanes were totally degraded as indicated by the GC-MS analyses in Figure 8. This is contrary to some studies which have reported slower degradation of branched chain alkanes compared to linear alkanes. Higher preference for straight chain alkanes compared to branched chain alkanes for instance was reported by [33]. In the present study however, most linear alkanes were still present at the end of the incubation period possibly due to their high concentration in diesel oil. Comparison of GC-MS profiles of control media with that inoculated with different isolates also revealed complete microbial degradation of aromatic hydrocarbons in spite of their persistent and recalcitrant nature. PAHs show greater resistance to degradation and are classified as persistent organic pollutants (POPs) [34]. Additionally, the ability of the isolates to reduce acyclic isoprenoid hydrocarbons, phytane and pristine normally used as internal biomarkers in environmental hydrocarbon analyses, suggest that the microbes possess multiple degradative genes which facilitate a diverse catabolic ability. Similar to the present study, numerous studies have also reported that phytane and pristine degradation remains slow until most alkanes are removed mainly due to their persistent nature $[35,36]$.

\subsection{AlkB Gene PCR Amplification}

Alkane hydroxylase gene of isolate $1 \mathrm{C}$ was successfully amplified and sequenced indicating the isolate's potential catabolic capability in degrading alkane fraction of petroleum oil. Isolate $2 \mathrm{C}$ did not give the expected PCR product size probably due to nonspecific priming while $3 \mathrm{~A}$ showed no PCR product for the gene. Lack of expected PCR products for this catabolic gene could be due to existence of completely different gene sequences from those characterized from the bacteria. Alternatively, regions used to develop the primer pair may not have been well conserved due to existence of gene homologues in this bacteria [37]. Phylogenetic analysis (Figure 9) indicated that the gene sequence for this isolate (1C) clustered with alkB gene from other $P$. aeruginosa strains with a posterior probability of $63 \%$ further supporting that isolate 1C is a Pseudomonas. AlkB gene catalyzes the first step in aerobic degradation of alkanes (medium and long chain) in which oxygen atom originating from molecular oxygen is introduced into the alkane substrate to form an alcohol. 


\section{Conclusion}

A total of twenty one microbes (20 bacteria and 1 fungus) were isolated from oil-contaminated soils sampled from garages around Ngara, Nairobi, Kenya. From these, nine efficient bacterial isolates were identified based on morphological and biochemical tests as well as 16S rDNA sequence analyses. The isolates were observed to utilize heating oil, hexane, octane and toluene as well as diesel oil as the sole carbon source. Optimization of culture conditions using three of the most efficient degraders revealed that optimal degradation of diesel oil was recorded with $<1 \%$ substrate concentration at $\mathrm{pH} 7$ and temperature range of between $30^{\circ} \mathrm{C}$ and $37^{\circ} \mathrm{C}$. Additionally, yeast extract was found to be the best nitrogen source for diesel oil biodegradation. GC-MS analyses demonstrated that the isolated bacterial strains were capable of readily degrading different alkane and aromatic hydrocarbons present in diesel oil thus exhibiting a broad range of catabolic activities. These findings clearly indicate the prospect to develop an environmentally friendly mitigation strategy against petroleum hydrocarbon pollution using the obtained bacterial isolates.

\section{Acknowledgements}

This research was supported by National Commission for Science, Technology and Innovation (NACOSTI) grant (NACOSTI/RCD/ST \& I/7thCALL/Msc/ 072).

\section{References}

[1] Jahangeer and Kumar V., "An overview on microbial degradation of petroleum hydrocarbon contaminants," International Journal of Engineering Research and Technology, 1(8). 34-37. 2013.

[2] Harayama S., Kishira H., Kasaia Y. and Shutsubo K., "Petroleum biodegradation in marine environments," Journal of molecular microbiology and biotechnology, 1(1). 63-70. 1999.

[3] Tebyanian H., Hassanshahian M. and Kariminik A., "Hexadecane-degradation by Teskumurella and Stenotrophomonas strains isolated from hydrocarbon contaminated soils," Jundishapur Journal of Microbiology, 6(7). 1-7. 2013.

[4] Das N. and Chandran P., "Microbial degradation of petroleum hydrocarbon contaminants: an overview," Biotechnology research international, 2011. 1-13. 2010.

[5] Zhu X., Venosa A. D., Suidan M. T. and Lee K., "Guidelines for the bioremediation of marine shorelines and freshwater wetlands," US Environmental Protection Agency, 2001.

[6] Rockne K. J. and Reddy K. R., "Bioremediation of contaminated sites," Invited Theme paper, international econference on modern trends in foundation engineering: geotechnical challenges and solutions, Indian Institute of Technology, Madras, India. 1-22. 2003.

[7] Lam S. S. and Chase H. A., "A review on waste to energy processes using microwave pyrolysis," Energies, 5(10). 42094232. 2012.

[8] Varjani S. J., Dolly P. R., Bateja S. and Upasani N. V., "Original research article isolation and screening for hydrocarbon utilizing bacteria (HUB) from petroleum samples," International Journal of Current Microbiology Applied Science, 2(4). 48-60. 2013.

[9] George-Okafor U., Tasie F. and Muotoe-Okafor F., "Hydrocarbon degradation potentials of indigenous fungal isolates from petroleum contaminated soils," Journal of Physical and natural sciences, 3(1). 1-6. 2009.

[10] Geetha S. J., Joshi S. J. and Kathrotiya S., "Isolation and characterization of hydrocarbon degrading bacterial isolated from oil contaminated sites." APCBEE Procedia, 5. 237-241. 2013.

[11] Afuwale C. and Modi H. A., "Study of bacterial diversity of crude oil degrading bacteria isolated from crude oil contaminated sites," Life sciences leaflets, 6. 13-23. 2012.

[12] Borah D. and Yadav R. N. S., "Optimization of BH medium for efficient biodegradation of diesel, crude oil and used engine oil by a newly isolated Bacillus cereus strain DRDU1 from an automobile engine," Biotechnology, 13(4). 181-185. 2014.

[13] Hucker G. J. and Conn H. J., "Methods of Gram staining," Technical Bullutin, 93. 1-37. 1923.

[14] Buck J. D., "Nonstaining ( $\mathrm{KOH})$ method for determination of gram reactions of marine bacteria," Applied and Environmental Microbiology, 44(4). 992-993. 1982.

[15] Miller D. N., Bryant J. E., Madsen E. L. and Ghiorse W. C., "Evaluation and optimization of DNA extraction and purification procedures for soil and sediment samples," Applied and environmental microbiology, 65(11). 4715-4724. 1999.

[16] Dasgupta D., Ghosh R. and Sengupta T. K., "Biofilmmediated enhanced crude oil degradation by newly isolated Pseudomonas species," ISRN biotechnology, 2013. 1-13. 2013.

[17] Merck, "Microbiology manual," $12^{\text {th }}$ Edition, pp. 1-169, Merck Publications, Darmstadt, Germany, 2007.

[18] Alariya S. S., Sethi S., Gupta S. and Lal G. B., "Amylase activity of a starch degrading bacteria isolated from soil," Archives of applied science Research, 5(1). 15-24. 2013.

[19] Kumari N., Vashishtha A., Saini P. and Menghani E., "Isolation, identification and characterization of oil degrading bacteria isolated from the contaminated sites of Barmer, Rajasthan," International Journal of Biotechnology and Bioengineering Research, 4(5). 429-436. 2013.

[20] Dongfeng Z., Weilin W., Yunbo Z., Qiyou L., Haibin Y. and Chaocheng Z., "Study on isolation, identification of a petroleum hydrocarbon degrading bacterium Bacillus fusiformis sp. and influence of environmental factors on degradation efficiency," Environment Protection, 13(4). 74-82. 2011.

[21] Shahaby A. F., Alharthi A. A. and El Tarras A. E., "Bioremediation of petroleum oil by potential biosurfactantproducing bacteria using Gravimetric assay," International Journal of Current Microbiology and Applied Sciences, 4(5). 390-403. 2015. 
[22] Corp, I. B. M. "SPSS Statistics for Windows, Version 19.0." (2010) SPSS.

[23] Hassanshahian M., Emtiazi G., and Cappello S., "Isolation and characterization of crude-oil-degrading bacteria from the Persian Gulf and the Caspian Sea," Marine pollution bulletin, 64(1). 7-12. 2012.

[24] Gagandeep S. and Malik D. K., "Utilization of 2T engine oil by Pseudomonas $s p$. isolated from automobile workshop contaminated soil," International Journal of Chemical and Analytical Science, 4(2). 80-84. 2013.

[25] Mahjoubi M., Jaouani A., Guesmi A., Ben Amor S., Jouini A., Cherif H., Najjari A., Boudabous A., Koubaa N. and Cherif A., "Hydrocarbonoclastic bacteria isolated from petroleum contaminated sites in Tunisia: isolation, identification and characterization of the biotechnological potential," New biotechnology, 30(6). 723-733. 2013.

[26] Taylor W. I. and Achanzar D., "Catalase test as an aid to the identification of Enterobacteriaceae," Applied microbiology, 24(1). 58-61. 1972.

[27] Sharma D., Ansari M. J., Al-Ghamdi A., Adgaba N., Khan K. A., Pruthi V. and Al-Waili N., "Biosurfactant production by Pseudomonas aeruginosa DSVP20 isolated from petroleum hydrocarbon-contaminated soil and its physicochemical characterization," Environmental Science and Pollution Research, 22(22). 17636-17643. 2015.

[28] Silva R. M. P., Rodríguez A. A., De Oca J. M. G. M. and Moreno D. C., "Biodegradation of crude oil by Pseudomonas aeruginosa AT18 strain," Tecnología Química, 26(1). 70-77. 2006.

[29] Rodrigues D. F., Sakata S. K., Comasseto J. V., Bicego M. C., and Pellizari V. H., "Diversity of hydrocarbon-degrading Klebsiella strains isolated from hydrocarbon-contaminated estuaries," Journal of applied microbiology, 106(4). 13041314. 2009.
[30] Barkay T., Navon-Venezia S., Ron E. Z. and Rosenberg E., "Enhancement of solubilization and biodegradation of polyaromatic hydrocarbons by the bioemulsifier alasan," Applied and environmental microbiology, 65(6). 2697-2702. 1999.

[31] Hamzah A., Rabu A., Farzarul R., Azmy H. R. and Yussoff N. A., "Isolation and characterization of bacteria degrading Sumandak and South Angsi oils," Sains Malaysiana 39(2). 161-168. 2010.

[32] Mahalingam P. U. and Sampath N., "Optimization of growth condition for diesel oil degrading bacterial strains," Advances in Applied Science Research, 5(6). 91-96. 2014.

[33] Katsivela E., Moore E. R. B. and Kalogerakis N., "Biodegradation of aliphatic and aromatic hydrocarbons: specificity among bacteria isolated from refinery waste sludge," Water, Air and Soil Pollution: Focus, 3(3). 103-115. 2003.

[34] Ferrarese E., Andreottola G. and Oprea I. A., "Remediation of PAH-contaminated sediments by chemical oxidation," Journal of Hazardous Materials, 152(1). 128-139. 2008.

[35] Mills M. A., Bonner J. S., McDonald T. J., Page C. A. and Autenrieth R. L., "Intrinsic bioremediation of a petroleumimpacted wetland," Marine Pollution Bulletin, 46(7). 887-899. 2003.

[36] Salam L. B., "Metabolism of waste engine oil by Pseudomonas species," 3 Biotech, 6(1). 1-10. 2016.

[37] Katsivela E., Moore E. R. B., Maroukli D., Strömpl C., Pieper D. and Kalogerakis N., "Bacterial community dynamics during in-situ bioremediation of petroleum waste sludge in landfarming sites," Biodegradation, 16(2). 169-180. 2005. 